\title{
Dominance of potentially toxic cyanobacteria on the waterfront of Santarém, Tapajós River, Brazilian Amazon
}

The present study carried out an evaluation of physicochemical parameters of waters from the low Tapajós river, and the identification of dominant cyanobacteria in the blooms that occurred in a transect bordering the Santarém city waterfront, in the State of Pará, Brazilian Amazon. Five (5) sampling stations were selected along the waterfront (RT-E1, RT-E2, RT-E3, RT-E4, RTE5), where water, phytoplankton and general environmental data were collected during 10 field campaigns, at intervals of 48 hours, between January 13th and 31st 2015, at the very beginning of the rainy season. The sample collections were conducted at an average depth of 2.3 meters, always early in the morning and following the procedures of the Collection and Preservation Guide and Water Samples of the Brazilian National Water Agency. Quantitative analyses of the physicochemical parameters were performed, namely: hydrogenionic potential $(\mathrm{pH})$; water temperature $\left({ }^{\circ} \mathrm{C}\right)$; turbidity (NTU); electrical conductivity (EC); Dissolved Oxygen (DO); nitrate (NO-3); nitrite (NO-2); ammonium ion (NH4); ammonia (NH3); orthophosphate (PO43-); phosphate (P2O5); phosphorus (P); iron (Fe) and chlorophyll a (Chlo a). General descriptive statistics were calculated. For counting of individuals, the efficiency was superior to $80 \%$, reaching a total of 3,910 individuals, from which $38 \%$ are species of the Cyanophyta division. The following species were dominant: Synechocystis aquatilis Microcystis aeruginosa, Dolichospermum spiroides, Nostoc sp. Except for $\mathrm{S}$. aquatilis, all the others are cyanotoxin producers that can be released into the water after cell disruption. The presence of cyanobacteria potentially producing cyanotoxins is of concern and should be considered in the diagnosis of waterborne diseases, such as hepatic infections that affect the riverine population of the Tapajós river.

\section{Domínio de cianobactérias potencialmente tóxicas na beira do Rio de Santarém, Rio Tapajós, Amazônia Brasileira}

\begin{abstract}
O presente estudo realizou uma avaliação dos parâmetros físico-químicos das águas do baixo rio Tapajós e a identificação de cianobactérias dominantes nas flores que ocorreram em um transecto na orla da orla da cidade de Santarém, no estado do Pará, Amazônia brasileira. Cinco (5) estações de amostragem foram selecionadas ao longo da orla (RT-E1, RT-E2, RT-E3, RT-E4, RTE5), onde foram coletados dados de água, fitoplâncton e dados ambientais gerais durante 10 campanhas de campo, em intervalos de 48 horas. entre 13 e 31 de janeiro de 2015, bem no início da estação chuvosa. As coletas de amostras foram realizadas a uma profundidade média de 2,3 metros, sempre de manhã e seguindo os procedimentos do Guia de Coleta e Preservação e Amostras de Água da Agência Nacional de Águas. Foram realizadas análises quantitativas dos parâmetros físico-químicos, a saber: potencial hidrogeniônico (pH); temperatura da água (ㅇ) ; turbidez (NTU); condutividade elétrica (CE); Oxigênio Dissolvido (DO); nitrato (NO-3); nitrito (NO-2); íon amônio (NH4); amônia (NH3); ortofosfato (PO43-); fosfato (P2O5); fósforo (P); ferro (Fe) e clorofila a (Chlo a). Estatísticas descritivas gerais foram calculadas. Para a contagem de indivíduos, a eficiência foi superior a $80 \%$, atingindo um total de 3.910 indivíduos, dos quais 38\% são espécies da divisão Cyanophyta. As seguintes espécies foram dominantes: Synechocystis aquatilis, Microcystis aeruginosa, Dolichospermum spiroides, Nostoc sp. Com exceção de $\mathrm{S}$. aquatilis, todos os outros são produtores de cianotoxinas que podem ser liberadas na água após a ruptura das células. A presença de cianobactérias potencialmente produtoras de cianotoxinas é preocupante e deve ser considerada no diagnóstico de doenças transmitidas pela água, como infecções hepáticas que afetam a população ribeirinha do rio Tapajós.
\end{abstract}

Palavras-chave: Parâmetros físico-químicos; Bloom; Cianotoxinas; América do Sul.

Topic: Engenharia de Recursos Hídricos

Reviewed anonymously in the process of blind peer.
Received: 02/10/2020

Approved: 24/11/2020
Keely Meireles Araújo Torres (iD)

Universidade Federal do Oeste do Pará, Brasil

http://lattes.cnpq.br/0888912986583609

http://orcid.org/0000-0001-6486-6995

keelymeirelles@gmail.com

Ruy Bessa Lopes (iD)

Universidade Federal do Oeste do Pará, Brasil

http://lattes.cnpq.br/4195469692527946

http://orcid.org/0000-0002-4806-8835

ruybessa@yahoo.com.br

Carlos José Sousa Passos (iD

Universidade de Brasília, Brasil

http://lattes.cnpq.br/6429611154970694

http://orcid.org/0000-0002-0553-9342

cjpassos@unb.br

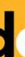

DOI: 10.6008/CBPC2179-6858.2020.006.0025

\author{
Andreia Cavalcante Pereira (ic) \\ Universidade Federal do Oeste do Pará, Brasil \\ http://lattes.cnpq.br/7088943165048531 \\ http://orcid.org/0000-0003-4261-7087 \\ diatomaceas@gmail.com
}

Lucinewton Silva de Moura (iD

Universidade Federal do Oeste do Pará, Brasil

http://lattes.cnpq.br/2577499231565227

http://orcid.org/0000-0002-9266-946X

lucinewton.moura@yahoo.com.br

\section{Referencing this:}

TORRES, K. M. A.; LOPES, R. B.; PASSOS, C. J. S.; PEREIRA, A. C.; MOURA, L. S.. Dominance of potentially toxic cyanobacteria on the waterfront of Santarém, Tapajós River, Brazilian Amazon. Revista Ibero Americana de Ciências Ambientais, v.11, n.6, p.298-314, 2020. DOI: http://doi.org/10.6008/CBPC2179-6858.2020.006.0025 


\section{INTRODUCTION}

The excess of nutrients in aquatic ecosystems, particularly nitrogen and phosphorus, resulting from their use as fertilisers in the agriculture, untreated sewage discharge, erosion, high rates of urbanisation, and lack of basic sanitation, among other factors, lead and/or intensify the bloom of algae in waterbodies, in a process known as cultural eutrophication (PAPPAS et al., 1996). Among the algae that form the bloom in fresh and brackish waters, we find some species of cyanobacteria which are vertical migrants and floaters, and thus may dominate the bloom whenever the water column stabilises (ESTEVES, 2011).

The Phylum Cyanobacteria Stanier ex Cavalier-Smith, according to Algaebase, there are over 4700 names (ANA, 2012), is a typical representative of the diverse species-rich group of microorganisms distributed environments worldwide. They are photosynthetic organisms and primary producers as eukaryotic algae, but do not hold cellular content and membrane-delimitated structures, resembling to bacteria (SIOLI, 1991). Under normal conditions, the cyanobacteria are less efficient in terms of nutrient assimilation than microalgae (green or diatomaceous). However, a higher offer of nutrient facilitates the sudden assimilation and growth under the form of bloom (HUSZAR et al., 2000; AZEVEDO et al., 2003).

The presence of the bloom with dominance of cyanobacteria directly interferes on the water quality, with negative effects for public health due to the production and liberation of potentially toxic and carcinogenic compounds (cyanotoxins). In Brazil, the most notorious case of cyanotoxin contamination occurred in Caruaru, State of Pernambuco, where the presence of microcystins-LR (MCLR) was detected, which is an hepatotoxin that can cause severe damage to the liver tissue. The MCLR was present at the Tabocas Local Water Reservoir (açude), which provided water to the reservoir of the Institute of Renal Diseases of Caruarú City, and cause the death of 70 haemodialysis patients back in 1996 (MATTHIENSEN et al., 1999). This case became known as 'The Caruarú Case' and was preponderant for the bloom of toxic cyanobacteria in waters to considered as a serious public health issue, which in turn was further regulated by the Brazilian National Council for the Environment (CONAMA) through the Resolution \#357/05 (MMA, 2005) as well as the Ministry of Health Instruction 2.914/2011, turning mandatory the monitoring of cyanobacteria at sites of surface water catchments (MMA, 2005), and recommends that the chlorophyll $\boldsymbol{\alpha}$ parameter be weekly monitored for re-evaluation of the cyanobacteria sampling frequency.

The dominance of cyanobacteria in aquatic environments depends on the coincidence of four main

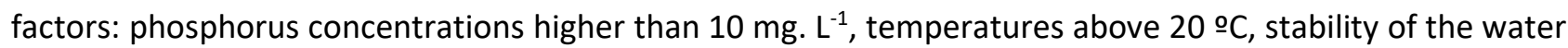
column, and pre-existing populations that contain vesicles (known as aerotopic), which allow the fluctuation and permanence of cyanobacteria on the water surface (AZEVEDO et al., 2003).

The Tapajós River, one of the most important tributaries of the Amazon River, presents these factors, and even though in their headwaters the values of the measured Trophic State Index (TSI) follow the limits allowed by the CONAMA Resolution \# 357/05 (being the maximum of 50.000 cells of cyanobacteria per $1 \mathrm{~mL} . \mathrm{L}^{-}$ ${ }^{1}$ for waters class 2 as the ones of the Tapajós), a huge the bloom of cyanobacteria has been observed over the last years on the shores of this large river, in front of the City of Santarém, western region of the State of 
Pará. In 2010, a the bloom of around 5 kilometres long occurred, which was documented by and by the Water Quality Project. The analysis of this the bloom confirmed the presence of two genera of cyanobacteria that are potentially toxin producers (Dolichospermum and Microcystis), which in turn obliged the State Sewage Company to avoid catching waters of the river, instead using underground water for consumption of the population.

Indeed, natural and anthropogenic variables contribute to patterns of variation that reflect on the algae population's cycles (REBOUÇAS et al., 2006). Human activities have been causing an increasing artificial enrichment of aquatic ecosystems by such nutrients as nitrogen and phosphorus that come from different sources: the use of agricultural fertilisers, the discharge of industrial and domestic sewage without adequate treatment, erosion caused by destruction of riparian forests, high rates of urbanisation and lack of basic sanitation (CARVALHO et al., 2008).

Since the availability of these nutrients in association with environmental factors like radiation, temperature and water $\mathrm{pH}$, and with anthropic factors, such as, occupation of the physical environment and socioeconomic activities, all influence water quality and phytoplankton productivity, it is important and necessary to distinguish the natural characteristics of the waterbodies from those caused and changed by human actions (ESTEVES, 2011). Thus, the present study assessed physicochemical parameters of waters from the low Tapajós river, and identified dominant cyanobacteria in a the bloom that occurred in a transect that covers the waterfront of the City of Santarém, western Pará, in the Brazilian Amazon.

\section{METHODOLOGY}

\section{Study area}

The municipality of Santarém has 294,580 inhabitants, an area of 22,887 square kilometres and a demographic density of 12.8 inhabitants per square kilometres (IBGE, 2010). Its annual mean temperature is $27.7 \stackrel{\circ}{ } \mathrm{C}$, and its rainfall is of 2,200 millimetres per annum. Assuming the Köppen-Geiger climate classification, Santarém is classified as Am, with more rainy periods comprised between the months of December to June, and less rainy from July through November (MIRANDA et al., 2009).

This city is located on the right bank of the Tapajós river (2일 $30^{\prime \prime}$ southern latitude and $544^{\circ} 42^{\prime} 50^{\prime \prime}$ western longitude). The waterfront is one of its postcards, where one can see the meeting of the waters from the Amazon and Tapajós. In this area, there are daily activities of tourism, leisure, commerce, port and aquatic activities that were all crucial at the time of selecting the sampling sites on the low Tapajós river over a transect that covers the city's waterfront (Fig. 1).

The year of 2015 was subject to the phenomenon of El Niño, and there was a delay of the rainy season, which commenced only at the second half of January. Two months earlier (November and December 2014), it was possible to carry out the environmental recognition of the study area, with previous visits to the waterfront of the Tapajós river and photographic documentation and preparation of a waterfront sketch, at the same time identifying points of sewage discharge from commercial and residential sources. At some 
points these open-air sewers run with more intense fluxes, dragging waste that is dumped untreated, directly into the river. Thus, the choice of water sampling stations was made due to the port activity and magnitude of the nearby sewage points, considering the magnitude of the sewage size on a scale of 1 to 5 , with 1 being smaller and 5 maximum magnitude (Table 1 ).

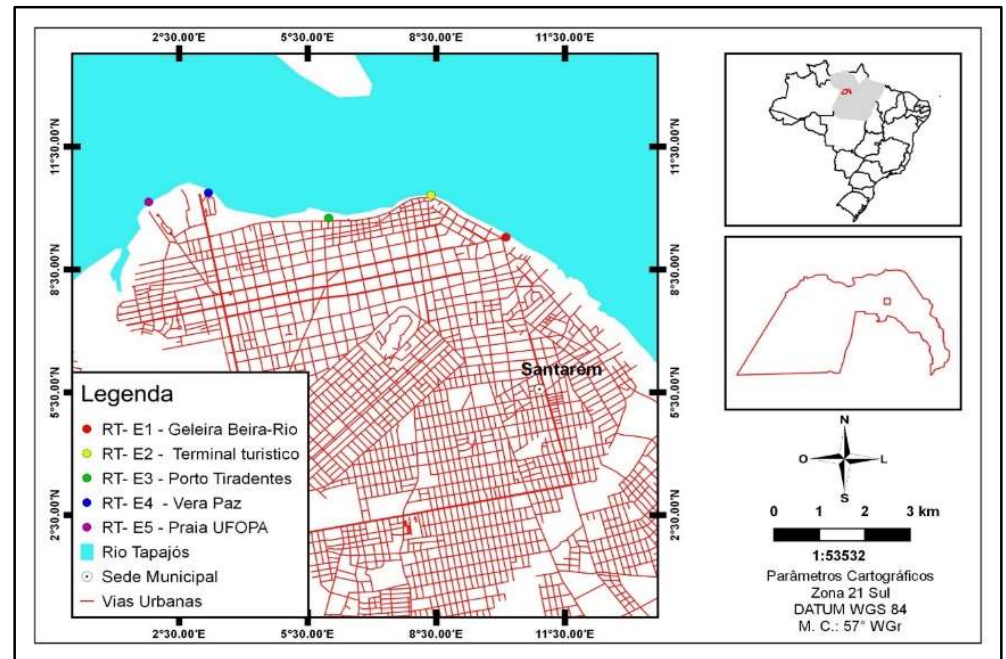

Fig. 1: Map of the transect location on the border of the Municipality of Santarém (Produced using the. Quantum GIS Software, Version 2.14).

Table 1: Characterisation and location of sampling sites.

\begin{tabular}{|c|c|c|}
\hline STATION & REFERENCE & DESCRIPTION \\
\hline $\begin{array}{l}\text { Tapajós } \\
\text { River } \\
\text { Station } 1 \\
\text { RT- E1 }\end{array}$ & $\begin{array}{l}\text { S 02 } 25^{\prime} 14.4^{\prime \prime}, \text { W } 05442^{\prime} \\
12.1^{\prime \prime}\end{array}$ & $\begin{array}{l}\text { Fishing port and ice supply. It has } 3 \text { points of medium size sewers discharge } \\
\text { (magnitude } 3 \text { ) }\end{array}$ \\
\hline $\begin{array}{l}\text { Tapajós } \\
\text { River } \\
\text { Station } 2 \\
\text { RT- E2 }\end{array}$ & 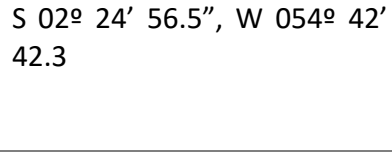 & River tourist terminal. It has 2 discharge points of large sewage (4) \\
\hline $\begin{array}{l}\text { Tapajós } \\
\text { River } \\
\text { Station } 3 \\
\text { RT- E3 }\end{array}$ & $\begin{array}{l}\text { S 02 } 24^{\prime} 56.5^{\prime \prime}, \text { W 054 } 42^{\prime} \\
42.3^{\prime \prime}\end{array}$ & $\begin{array}{l}\text { Right side of the Tiradentes Port. Greater port activity. } 1 \text { sewer of greater } \\
\text { magnitude (5) }\end{array}$ \\
\hline $\begin{array}{l}\text { Tapajós } \\
\text { River } \\
\text { Station } 4 \\
\text { RT- E4 }\end{array}$ & $\begin{array}{l}\text { S 02 } 24^{\prime} 55.3^{\prime \prime}, \text { W 054우 44' } \\
11.7^{\prime \prime}\end{array}$ & Vera Paz Port, near the Cargill Port. It has 2 points of large sewer discharge (4) \\
\hline $\begin{array}{l}\text { Tapajós } \\
\text { River } \\
\text { Station } 5 \\
\text { RT- E5 }\end{array}$ & $\begin{array}{l}02024^{\prime} 59.3^{\prime \prime}, \text { W } 054 \text { - 44' } \\
35.8^{\prime \prime}\end{array}$ & $\begin{array}{l}\text { UFOPA beach, reform of boats and rafts. It has } 2 \text { discharge points of small to } \\
\text { medium sewage ( } 2 \text { ) }\end{array}$ \\
\hline
\end{tabular}

\section{Sample collection and storage procedures}

Ten water sampling campaigns were conducted at the beginning of the rainy season, with a 48-hour interval between campaigns, and performed at an average depth of 2.3 meters, always in the morning and following the procedures described in the Collection Guide and Preservation of Water Samples from the Environmental Technology and Sanitation Company of the National Water Agency (ANA, 2012; APHA, 1915).

After a thorough review of the literature, 15 physicochemical parameters of the water were selected for analysis within the present study (ESTEVES, 2011; AZEVEDO et al., 2003; GENTIL et al., 2008; MIRANDA et 
al., 2009; SÁ et al., 2010) namely: dissolved oxygen concentration (DO mg/L); Dissolved oxygen saturation (DO\%); Hydrogenation potential $(\mathrm{pH})$; Water temperature $\left({ }^{\circ} \mathrm{C}\right)$; Turbidity (NTU); Electrical conductivity (EC), nitrate $\left(\mathrm{NO}_{3}\right)$; Nitrite $\left(\mathrm{NO}_{2}\right)$; Ammonium ion $\left(\mathrm{NH}_{4}\right)$; Ammonia $\left(\mathrm{NH}_{3}\right)$; Orthophosphate $\left(\mathrm{PO}_{4}{ }^{3}\right)$; Phosphate $\left(\mathrm{P}_{2} \mathrm{O}_{5}\right)$; Phosphorus (P); Iron (Fe) and chlorophyll a (Chlo $\alpha$ ). These parameters were analysed quantitatively, except for phytoplankton that was also analysed qualitatively.

For the quantitative study, the samples were collected using a vertical Van Dorn acrylic bottle (3 liters), $50 \mathrm{~cm}$ from the bottom and at the base of the euphotic zone, composing integrated samples. They were then stored in polyethylene bottles of $300 \mathrm{~mL}$, one sample from each station fixed in $5 \%$ Lugol and the rest refrigerated at $4^{\circ} \mathrm{C}$ for nutrient analysis.

In the RT-E2 and RT-E4 sample stations (Table 1), $600 \mathrm{~mL}$ were stored in dark polyethylene bottles, which after arrival in the laboratory were filtered through a glass fiber filter ( $47 \mathrm{~mm}$ of diameter with porosity between 0.45 and $1.0 \mu \mathrm{m}$ ) for phytoplankton compaction. The filters of the samples and replicates were duly waterproofed and frozen in the freezer of the Laboratory of Environmental Chemistry of UFOPA - Tapajós Campus.

Samples for the qualitative analysis of phytoplankton were collected with plankton netting with 20 $\mu \mathrm{m}$ mesh, which was drawn horizontally and fixed in $4 \%$ formalin solution. The physical parameters were measured in loco, attesting values for: hydrogenation potential ( $\mathrm{pH}-\mathrm{MS} \mathrm{pH}$ TECNOPON $\left.{ }^{\circledR}\right)$; Water temperature (To - YSI ${ }^{\circledast}$ probe); Electrical conductivity (EC - Metalyser ${ }^{\circledR}$ conductivity meter); Concentration of dissolved oxygen (OD-LOVIIBOND Oximeter) and turbidity (NTU -Turbidimeter POLICONTROL ${ }^{\circledR}$ ).

\section{Sample analyses}

In the laboratory of Applied Chemistry (Institute of Water Science and Technology, Federal University of Western Pará - ICTA/UFOPA), the nutrient analysis was carried out, according to Standard Methods, using multi-parametric and photometric probe (HANNA Instruments model $\mathrm{HI} 830999$ ), set at $25^{\circ} \mathrm{C}$, following the sample preparation method and using reagents described in the manufacturer's guide, for the analysis of each nutrient, values were obtained: $\mathrm{NO}_{3} ; \mathrm{NO}_{2} ; \mathrm{NH}_{4} ; \mathrm{NH}_{3} ; \mathrm{PO}_{4}{ }^{3} ; \mathrm{P}_{2} \mathrm{O}_{5} ; \mathrm{P}$ and $\mathrm{Fe}$.

For the counting of the cyanobacteria, the samples fixed in Lugol 5\% and the method of (UTERMÖHL, 1958) for sedimentation were used, following to an inverted Zeiss Axiovert 125 microscope, where each cell, colony, colonnade or filament was considered as an individual (GENTIL, 2008). For the counting of the number of fields, $80 \%$ efficiency was accepted, by the method of (PAPPAS et al., 1996), according to the equation 1:

$$
\text { Efficiency }(\%)=1-\frac{\text { Number of Species }}{\text { Number of Individuals }}
$$

For the determination of Chlorophyll a, filters and frozen replicates were used, where the compacted phytoplankton was analysed by the methodology described by modified by (STRICKLAND et al., 1965) and (TEIXEIRA, 1973), and available in. In the spectrophotometer, the optical densities were determined in the wavelengths, aiming to obtain the result of the total photosynthetic pigment or chlorophyll a calculated by 
the following equation 2 :

chlo $\alpha=\frac{11,6 \times D 665-(1,31 \times D 645+0,14 \times D 630+D 750) \times V 1}{V 2 \times L}$

where:

11.6; 1.31 and 0.14 are constants;

D - Absorbance readings at wavelengths $665 \mathrm{~nm}, 645 \mathrm{~nm}, 630 \mathrm{~nm}$ and $750 \mathrm{~nm}$; V1 - $90 \%$ acetone volume $(0.01 \mathrm{~L}$ or $10 \mathrm{~mL})$;

V2- volume of the filtered sample in litres $(0.3 \mathrm{~L}$ or $300 \mathrm{~mL})$;

L- Bucket optical path $(1 \mathrm{~cm})$.

For the taxonomic analyses, slides and coverslips were prepared. By using a binocular microscope Zeiss Axio with photographic camera coupled to the optical system, we took photomicrographs to assist in the identification of cyanobacteria species. The results obtained in the analysis of the physicochemical parameters and of chlorophyll 'a' were analysed by descriptive statistics and using the Excel Software Version 2013 of the Microsoft Office Package.

\section{RESULTS AND DISCUSSION}

\section{Environmental characteristics of study area}

Table 2 presents descriptive statistics for the physicochemical parameters assessed during the 10 field campaigns conducted throughout the study ( $n=50$ samples), in addition to values found for Chlorophyll a, the latter only for the samples from the stations RT-E2 e RT-E4 (Table 2).

Table 2: Descriptive statistics of water physicochemical variables on the studied transect, Waterfront of Santarém (Pará).

\begin{tabular}{|c|c|c|c|c|c|c|c|c|c|c|c|c|c|c|c|}
\hline & & RT-E1 & & RT-E2 & & RT-E3 & & & RT-E4 & & & & & & \\
\hline $\begin{array}{l}\text { Variabl } \\
\text { e }\end{array}$ & $\begin{array}{l}\text { Min } \\
- \\
\text { Max }\end{array}$ & $\begin{array}{l}\text { Mea } \\
n\end{array}$ & SD & $\begin{array}{l}\text { Min- } \\
\text { Max }\end{array}$ & $\begin{array}{l}\text { Mea } \\
n\end{array}$ & SD & $\begin{array}{l}\text { Min } \\
- \\
\text { Max }\end{array}$ & $\begin{array}{l}\text { Mea } \\
n\end{array}$ & SD & $\begin{array}{l}\text { Min- } \\
\text { Max }\end{array}$ & $\begin{array}{l}\text { Mea } \\
n\end{array}$ & SD & $\begin{array}{l}\text { Min } \\
- \\
\text { Max }\end{array}$ & $\begin{array}{l}\text { Mea } \\
\mathrm{n}\end{array}$ & SD \\
\hline $\begin{array}{l}\mathrm{NO}_{3} \\
\left(\mathrm{mg} \cdot \mathrm{L}^{-1}\right)\end{array}$ & $\begin{array}{l}1,9- \\
10,5\end{array}$ & 6,83 & $\begin{array}{l}2,9 \\
7\end{array}$ & $\begin{array}{l}1- \\
15,9\end{array}$ & 7,15 & 5,11 & $\begin{array}{l}4,6- \\
15\end{array}$ & 9,67 & 4,11 & $\begin{array}{l}4,8- \\
15,1\end{array}$ & 8,37 & 3,49 & $\begin{array}{l}0,2- \\
17,8\end{array}$ & 7,51 & 5,78 \\
\hline $\begin{array}{l}\mathrm{NO}_{2} \\
\left(\mathrm{mg} \cdot \mathrm{L}^{-1}\right)\end{array}$ & $\begin{array}{l}0,02 \\
- \\
0,08\end{array}$ & $\begin{array}{l}0,03 \\
8\end{array}$ & $\begin{array}{l}0,0 \\
2\end{array}$ & $\begin{array}{l}0,02- \\
0,11\end{array}$ & 0,04 & 0,03 & $\begin{array}{l}0,02 \\
- \\
0,06\end{array}$ & 0,04 & 0,01 & $\begin{array}{l}0,02- \\
0,05\end{array}$ & 0,04 & 0,01 & $\begin{array}{l}0,03 \\
- \\
0,06\end{array}$ & 0,04 & 0,01 \\
\hline $\begin{array}{l}\text { NH4 } \\
\left(\mathrm{mg} \cdot \mathrm{L}^{-1}\right)\end{array}$ & $\begin{array}{l}0- \\
0,73\end{array}$ & $\begin{array}{l}0,42 \\
1 \\
\end{array}$ & $\begin{array}{l}0,2 \\
0\end{array}$ & $\begin{array}{l}0,38- \\
0,59\end{array}$ & 0,49 & 0,09 & $\begin{array}{l}0- \\
0,66\end{array}$ & 0,40 & 0,24 & $\begin{array}{l}0,39- \\
0,93\end{array}$ & 0,51 & 0,16 & $\begin{array}{l}0- \\
1,91\end{array}$ & 0,53 & 0,51 \\
\hline $\begin{array}{l}\mathrm{NH}_{3} \\
\left(\mathrm{mg} \cdot \mathrm{L}^{-1}\right)\end{array}$ & $\begin{array}{l}0- \\
0,69 \\
\end{array}$ & $\begin{array}{l}0,39 \\
8\end{array}$ & $\begin{array}{l}0,1 \\
9\end{array}$ & $\begin{array}{l}0,35- \\
0,56\end{array}$ & 0,47 & 0,08 & $\begin{array}{l}0- \\
0,62 \\
\end{array}$ & 0,37 & 0,22 & $\begin{array}{l}0,37- \\
0,88\end{array}$ & 0,48 & 0,15 & $\begin{array}{l}0- \\
1,8 \\
\end{array}$ & 0,51 & 0,48 \\
\hline $\begin{array}{l}\mathrm{PO}^{3} 4 \\
\left(\mathrm{mg} \cdot \mathrm{L}^{-1}\right)\end{array}$ & $\begin{array}{l}0,4- \\
6,5\end{array}$ & 1,71 & $\begin{array}{l}1,8 \\
4\end{array}$ & $\begin{array}{l}0,3- \\
2,3\end{array}$ & 0,93 & 0,77 & $\begin{array}{l}0,5- \\
3,6\end{array}$ & 1,46 & 1,15 & $\begin{array}{l}0,4- \\
1,8\end{array}$ & 0,94 & 0,43 & $0-8$ & 1,87 & 2,44 \\
\hline $\begin{array}{l}\mathrm{P}_{2} \mathrm{O}_{5} \\
\text { (mg.L-1) }\end{array}$ & $\begin{array}{l}0,3- \\
4,9\end{array}$ & 1,29 & $\begin{array}{l}1,3 \\
9 \\
\end{array}$ & $\begin{array}{l}0,2- \\
1,7\end{array}$ & 0,68 & 0,56 & $\begin{array}{l}0,4- \\
2,7\end{array}$ & 1,11 & 0,86 & $\begin{array}{l}0,3- \\
1,4\end{array}$ & 0,69 & 0,33 & $0-6$ & 1,39 & 1,83 \\
\hline $\begin{array}{l}\text { P (mg.t- } \\
\text { 1) }\end{array}$ & $\begin{array}{l}0,1- \\
2,1\end{array}$ & 0,55 & $\begin{array}{l}0,6 \\
0\end{array}$ & $\begin{array}{l}0,1- \\
0,8\end{array}$ & 0,3 & 0,27 & $\begin{array}{l}0,2- \\
1,2\end{array}$ & 0,49 & 0,38 & $\begin{array}{l}0,1- \\
0,6\end{array}$ & 0,3 & 0,15 & $\begin{array}{l}0- \\
2,6\end{array}$ & 0,6 & 0,80 \\
\hline $\begin{array}{l}\text { Fe ( } \mu \mathrm{g} \cdot \mathrm{L}^{-} \\
\text {1) }\end{array}$ & $\begin{array}{l}106- \\
400\end{array}$ & $\begin{array}{l}186, \\
5\end{array}$ & $\begin{array}{l}97, \\
7\end{array}$ & $\begin{array}{l}48- \\
380\end{array}$ & $\begin{array}{l}188, \\
3\end{array}$ & $\begin{array}{l}100 \\
9\end{array}$ & $\begin{array}{l}132- \\
381\end{array}$ & $\begin{array}{l}227 \\
3\end{array}$ & $\begin{array}{l}88,7 \\
9 \\
\end{array}$ & $\begin{array}{l}70- \\
388\end{array}$ & $\begin{array}{l}191, \\
5\end{array}$ & $\begin{array}{l}92,5 \\
3\end{array}$ & $\begin{array}{l}85- \\
392\end{array}$ & $\begin{array}{l}195, \\
1\end{array}$ & $\begin{array}{l}93,5 \\
0\end{array}$ \\
\hline $\mathrm{T}(\mathrm{C})$ & $\begin{array}{l}28- \\
29\end{array}$ & $\begin{array}{l}28,6 \\
7\end{array}$ & $\begin{array}{l}0,3 \\
1\end{array}$ & $\begin{array}{l}26,8- \\
29,2\end{array}$ & $\begin{array}{l}28,5 \\
4\end{array}$ & 0,73 & $\begin{array}{l}28,4 \\
- \\
29,3 \\
\end{array}$ & $\begin{array}{l}28,8 \\
6\end{array}$ & 0,28 & $\begin{array}{l}28,5- \\
29,7\end{array}$ & $\begin{array}{l}29,1 \\
2\end{array}$ & 0,35 & $\begin{array}{l}28,2 \\
- \\
29,9 \\
\end{array}$ & $\begin{array}{l}29,2 \\
3\end{array}$ & 0,49 \\
\hline $\begin{array}{l}\text { CE } \\
\left(\mu S . \mathrm{cm}^{-}\right. \\
1)\end{array}$ & $\begin{array}{l}12,8 \\
- \\
31,6\end{array}$ & 19,3 & $\begin{array}{l}6,1 \\
8\end{array}$ & $\begin{array}{l}6,7- \\
17,3\end{array}$ & $\begin{array}{l}14,2 \\
1\end{array}$ & 2,96 & $\begin{array}{l}7,1- \\
22,4\end{array}$ & $\begin{array}{l}14,4 \\
4\end{array}$ & 4,88 & $\begin{array}{l}6,7- \\
16,1\end{array}$ & $\begin{array}{l}13,4 \\
6\end{array}$ & 3,60 & $\begin{array}{l}6,8- \\
16,1\end{array}$ & $\begin{array}{l}13,0 \\
5\end{array}$ & 3,41 \\
\hline $\begin{array}{l}\text { Turbidit } \\
\text { y (NTU) }\end{array}$ & $9-23$ & 14,1 & $\begin{array}{l}4,8 \\
4\end{array}$ & $8-16$ & 10 & 2,31 & $\begin{array}{l}10- \\
18\end{array}$ & 12,9 & 2,56 & $9-26$ & 12,3 & 5,21 & $9-17$ & 11,1 & 2,33 \\
\hline pH & $\begin{array}{l}5,44 \\
- \\
7,35\end{array}$ & $\begin{array}{l}6,13 \\
8\end{array}$ & $\begin{array}{l}0,7 \\
1\end{array}$ & $\begin{array}{l}5,52- \\
7,53\end{array}$ & 6,17 & 0,69 & $\begin{array}{l}5,66 \\
- \\
6,97\end{array}$ & 6,11 & 0,41 & $\begin{array}{l}5,68- \\
6,75\end{array}$ & 6,09 & 0,38 & $\begin{array}{l}5,46 \\
- \\
6,53\end{array}$ & 6,00 & 0,35 \\
\hline
\end{tabular}




\begin{tabular}{|c|c|c|c|c|c|c|c|c|c|c|c|c|c|c|c|}
\hline $\begin{array}{l}\text { OD } \\
\left(\mathrm{mg} \cdot \mathrm{L}^{-1}\right)\end{array}$ & $\begin{array}{l}0,1- \\
13,1\end{array}$ & 3,92 & $\begin{array}{l}5,7 \\
6 \\
\end{array}$ & $\begin{array}{l}0,1- \\
11,2\end{array}$ & 1,38 & 3,45 & $\begin{array}{l}0,1- \\
1,1\end{array}$ & 0,49 & 0,36 & $\begin{array}{l}0,3- \\
14,2\end{array}$ & 2,06 & 4,27 & $\begin{array}{l}0,1- \\
1,1\end{array}$ & 0,61 & 0,28 \\
\hline DO (\%) & $\begin{array}{l}17- \\
32,2\end{array}$ & $\begin{array}{l}22,7 \\
2\end{array}$ & $\begin{array}{l}5,5 \\
2\end{array}$ & $\begin{array}{l}17,4- \\
41,1\end{array}$ & $\begin{array}{l}24,7 \\
1\end{array}$ & 7,38 & $\begin{array}{l}16,9 \\
- \\
35,8\end{array}$ & 24,9 & 6,24 & $\begin{array}{l}15,5- \\
93,6\end{array}$ & $\begin{array}{l}30,5 \\
5\end{array}$ & $\begin{array}{l}22,6 \\
1\end{array}$ & $\begin{array}{l}14,8 \\
- \\
29,1\end{array}$ & $\begin{array}{l}21,6 \\
1\end{array}$ & 5,01 \\
\hline $\begin{array}{l}\text { CHLO- } \alpha \\
\left(\mu \mathrm{g} . \mathrm{L}^{-1}\right)\end{array}$ & & & & $\begin{array}{l}0,424 \\
- \\
1,621\end{array}$ & 0,78 & 0,36 & & & & $\begin{array}{l}0,579 \\
- \\
7,910\end{array}$ & 1,60 & 2,24 & & & \\
\hline
\end{tabular}

When analysing the concentrations found for nitrogen and phosphate nutrients, we observe they are below the reference values determined by the Brazilian National Council for the Environment (CONAMA), according to Resolution \# 357/2005, however phosphorus is a growing concern, as it is related to the eutrophication of waters. Table 3 presents some comparative values between the averages found and the reference values.

Table 3: Comparison of the analysed nutrients with regulatory limits.

\begin{tabular}{lll}
\hline NUTRIENT & REFERENCE VALUE & MEAN VALUE FOUND \\
\hline Total phosphorus $(\mathrm{P})$ & $0,1 \mathrm{mg} / \mathrm{L}$ & $0,448 \mathrm{mg} / \mathrm{L}$ \\
\hline Orthophosphate $\left(\mathrm{PO}_{4}{ }^{3-}\right)$ & $1 \mathrm{a} 5 \mathrm{mg} / \mathrm{L}$ & $1,382 \mathrm{mg} / \mathrm{L}$ \\
\hline Nitrate $\left(\mathrm{NO}_{3}{ }^{-}\right)$ & $10,0 \mathrm{mg} / \mathrm{L}$ & $7,99 \mathrm{mg} / \mathrm{L}$ \\
\hline Nitrite $\left(\mathrm{NO}_{2}{ }^{-}\right)$ & $1,0 \mathrm{mg} / \mathrm{L}$ & $0,014 \mathrm{mg} / \mathrm{L}$ \\
\hline
\end{tabular}

${ }^{1}$ According to CONAMA Resolution \#357/2005.

According to the Water Sample Collection and Preservation Guide, it is not recommended to take samples close to the banks of rivers, channels and at the point of dumping, except when these regions are of specific interest. In this case, the identification of the sampling site must take into account the existence of industrial and/or domestic liquid effluents, as well as the presence of tributaries in the area of influence of the sampling point, as these may alter the water quality of the sampling point. body.

In RT-E3, note that the nitrate values are always higher, precisely because of the contamination of the supply of organic matter from domestic sewage in the urban area and from vessels.

The Tapajós River has availability of nutrients and favorable climate, influenced by periods of flood and ebb and by not having significant differences in water depth and temperature between the collection stations. The average value of the water temperature was $28.9^{\circ} \mathrm{C}$, ideal for cyanobacteria, which in general have a higher tolerance to high temperatures, when compared with other algae.

In the newly formed domestic sewage, the predominant form of orthophosphate is $\mathrm{HPO}_{4}{ }^{2}$, which mostly originates from the phosphates, but as the sewage ages the orthophosphate takes the form of $\mathrm{PO}_{4}{ }^{3-}$, which is more available to aquatic organisms. On the other hand, particulate organic matter contains about $70 \%$ or more of the total organic phosphorus, whereas the rest is in dissolved or colloidal form, and its distribution is influenced by biotic factors (e.g., activity of autotrophic and heterotrophic organisms) as well as abiotic factors such as $\mathrm{pH}$ and temperature (ESTEVES, 2011).

Due to the lack of significant differences in depth, and assuming there were no large variations in the water temperature between the collection stations, the average temperature was $28.9{ }^{\circ} \mathrm{C}$, ideal for cyanobacteria, which are generally more tolerant to high temperatures when compared to other algae.

The $\mathrm{pH}$ values throughout the seasons varied from 5.4 to 7.5 , which are justified in a scenario of the 
blooms, high intensity of sunlight and the influence of the Amazon River that sometimes invades the studied area. According to (SIOLI, 1991), the water chemical analyses give indications about the soil types and the cationic layer of the clay fraction of the suspended material.

Turbidity in the studied transect showed a variation between 8 NTUs (Nephelometric Turbidity Unit) in RT-E2 and 26 NTUs in RT-E4, averaging 12.1 NTUs, and the RT-E4 station sheltering the Cargill bulk carrier port. These grains are dumped from a high conveyor belt, and during their launch into the holds of the ships they are aerated by the constant wind of the Santarém waterfront. At that moment, films and particles of these grains are dissipated, composing a dust that is deposited on the adjacent surface waters. Also, near this RT-E4 sampling station is located the State of Pará Port Authority as well as sewage and vegetation from the former Vera Paz beach area. All these elements result in the collection and accumulation of suspended particles that may explain the variation of the turbidity found in this and previous studies, such as the one by (MIRANDA et al., 2009) in the same area and period, where 76.4 NTUs were obtained, very different from the value found by (ABDO et al., 1997), which was 6.5 NTUs. All these values were below the 100 NTUs allowed by CONAMA Resolution 357/2005.

The maximum value of electrical conductivity recorded on RT-E1 was $31.6 \mu \mathrm{S} . \mathrm{cm}^{-1}$, within the allowed range for natural freshwater, which should be less than $500 \mu \mathrm{S} . \mathrm{cm}^{-1}$. The electrical conductivity is directly related to the concentration of dissolved ions, mainly inorganic. RT-E1 is the station with the highest dissolution power because it is in the most open part of the river mouth, and this station also has the lowest flow of vessels, receiving fishing boats that harbor for ice supply.

For dissolved oxygen, low values were found, such as a minimum of $0.11 \mathrm{mg} . \mathrm{L}^{-1}$, registered on RT-E3 that receives direct influence from the Tiradentes harbour, where there is the largest point of sewage, in addition to the continuous disposal of waste in natura from the toilets of riverboats arriving and departing daily with passengers to neighbour municipalities, to the State capital of Belém and to other states. The CONAMA Resolution 357/2005 establishes the maximum limit for dissolved oxygen of $5 \mathrm{mg}$. $\mathrm{L}^{-1}$, but in the samples collected on the Tapajós river transect bordering the Santarém waterfront, the mean dissolved oxygen concentration was $1.69 \mathrm{mg} . \mathrm{L}^{-1}$, indicating water pollution in the area, at least up to the studied depth.

It is common to observe that different factors may act together to contaminate areas similar to our study site, such as the sewers of the urban collecting network; erosion and deforestation, as well as the remains of public roads that are carried by the rainwater to the river (SANTOS et al., 2014); waste, sanitary waste from riverboats and garbage as well as wastes from the sinks of vessels that can act as organic and inorganic pollutants (MIRANDA et al., 2009); in addition, during the suply of ships with grain in the bulk carrier port of the multinational, a powder is loaded by the wind and deposited on the waters. This 'soybean dust' is a mixture of grain films, straws and other residues that could contribute to the nutrient supply at the RTE4 station. The nutrient load, resulting from all these factors, is discharged into the low Tapajós river, in front of the Santarém waterfront, without any treatment, and we strongly believe that it may play an important role in influencing the occurrence of the blooms in this area. For, there is evidence that the flowering in lotic environments in Brazil is due to the association of extensive summer periods, in which the absence of rainfall 
causes a low water flow rate, together with an ideal balance of nutrients that revolve in the first rains and, to the elevation of the temperature, providing conditions favorable to the occurrence of cyanobacteria the blooms.

During the low water period, the water level and flow decreases, reducing the dissolution capacity of this organic matter. Therefore, after the maximum point of the drought, in November (Fig. 2), there is a residue of this load that settled and was accumulated in the bottom, being revolved as soon as the rainy season begins, over the months of December or January, as observed in 2015. With the gradual increase of the water level of the low Tapajós river, the sediments and organic matter are revolved and the nutrients made available, and this contributes to the increase of the phytoplankton productivity and the appearance of the blooms that fill the spaces between the riverboats and port areas, modifying the landscape of the border of Santarém. Fig. 2 at RT-E4 station, where Cargill's bulk carrier port and the former Vera Paz beach are currently located.

The values marked on the ruler of the Brazilian Navy in Santarém for the years between 2005 and 2014 demonstrate how the level of the low Tapajós river at the mouth follows the pluviometric pattern, coinciding the peak of the flood (high waters) with the period of higher rainfall intensity, and the peak of drought (low water) with the lowest volume of rainfall in the region (Fig. 3). However, due to climatic differences in the distribution of rainfall in the Tapajós river basin, the mouth presents the highest percentage of headwater, and this differentiation of rainfall and drainage network behaviour in the basin (SANTOS et al., 2014) associated with a pattern of land use and occupation tends to aggravate the consequences of the less rainy season, especially in the waterfront of Santarém.

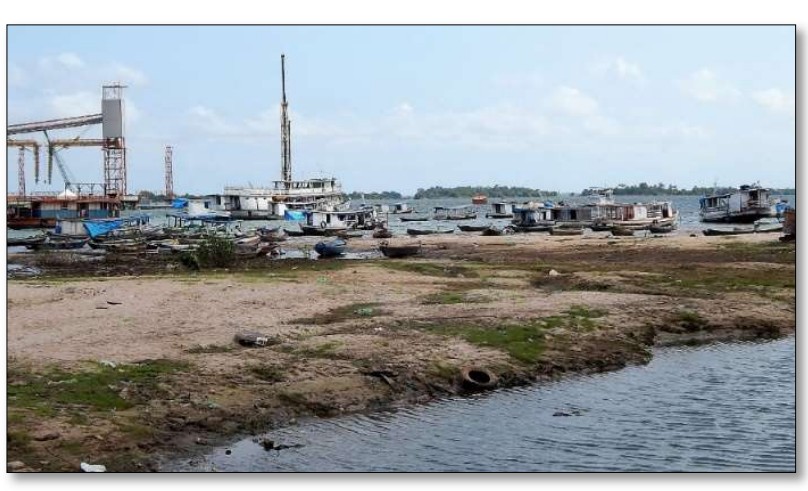

Fig. 2: The RT-E4 Station area during the dry season.

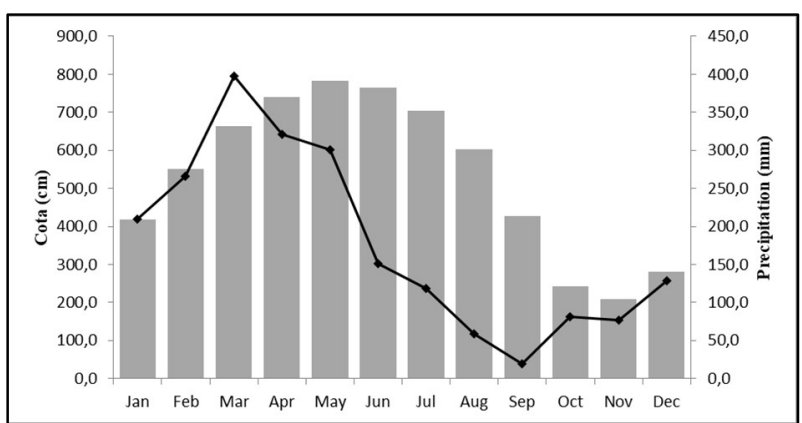

Fig. 3: Monthly means of Cota and precipitation on the Tapajós River (2005-2014). Source: Brazilian Navy Office in Santarém for the Cota; Station 82246 of the Brazilian National Institute for Meteorology (Belterra Municipality) for (precipitation).

According to (MATTHIENSEN et al., 1999), the bloom result from the interaction of physical, chemical and biological factors, and they are characterised by an explosive growth of the microorganisms of one or a few species, which although self-limiting and of short duration, often produce visible colorations on the natural waterbodies, generating problems that may range from landscape aesthetics to serious public and environmental health problems. As concerns phytoplankton algae, it is important to emphasize that their presence in freshwater is an important element for the evaluation of environmental conditions (GENTIL, 2008), since the low values of dissolved oxygen (DO) in water show a tendency for eutrophication and greater 
potential for the bloom of algae, especially cyanobacteria. Dissolved oxygen also influences the increase of iron (Fe) values in water, and according to (MIRANDA et al., 2009) the decrease of oxygen dissolved in water increases the reducing tendency of the medium, according to the equilibrium shown in equation3:

$$
2 \mathrm{Fe}^{2}+\frac{1}{2} \mathrm{O}_{2}+2 \mathrm{H}=2 \mathrm{Fe}^{3}+\mathrm{H}_{2} \mathrm{O}
$$

The values found for iron varied between 48 and $400 \mu \mathrm{g} . \mathrm{L}^{-1}$, different from the ones found by (MIRANDA et al., 2009) that varied from 4.77 to $15.91 \mu \mathrm{g} . \mathrm{L}^{-1}$, showing an increase in the studied perimeter in recent years states that in surface waters the level of iron increases during the rainy season due to the land cover and the occurrence of erosion processes of the banks. The presence of industrial effluents and/or industrial products used in activities to remove the oxidised layer (rust) also contributes to this increase.

Thus, the mean values found were higher at the RT-E3 station $\left(227.3 \mu \mathrm{g} . \mathrm{L}^{-1}\right)$, where is located the Port of Tiradentes with greater flow of port activity and the largest sewage. In addition, iron in the presence of organic matter dissolved in the surface waters may have its complexes altered and its solubility increased, presenting higher values. The second highest mean value was recorded at the sampling station RT-E5 (195.1 $\left.\mu \mathrm{g} . \mathrm{L}^{-1}\right)$, where boat and ferry reform activities are carried out with the use of chemical products, such as solvents (Fig. 4). These products come into contact with the water and their packaging is thrown on the beach, contaminating the sand and consequently the river when loaded with rainwater.

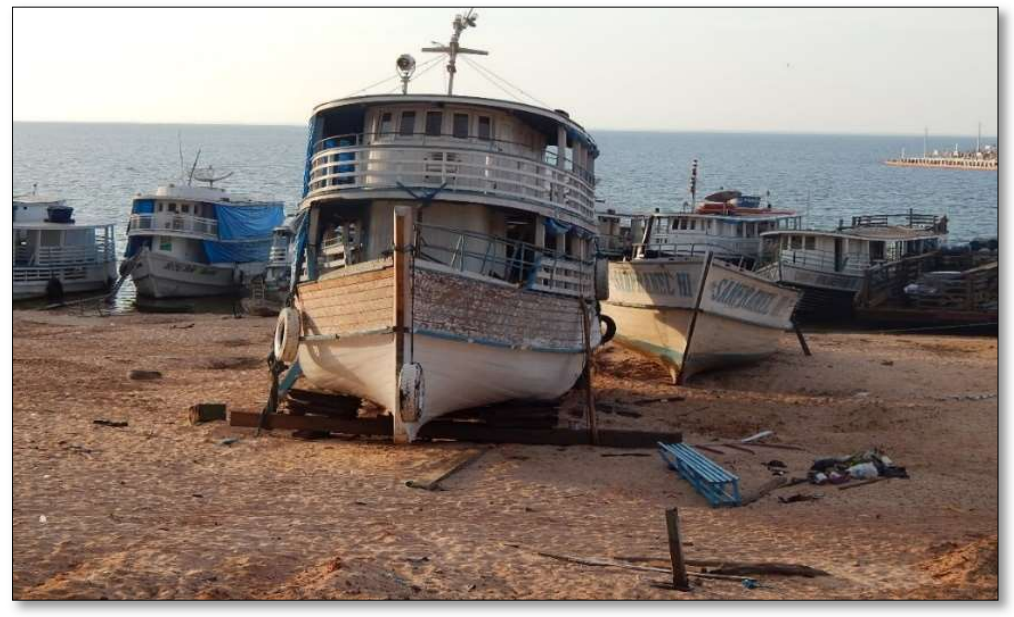

Fig. 4: The RT-E5 station area with open-air yards.

\section{Phytoplankton Community Analyses}

We found 103 taxa, distributed into 8 taxonomic classes or divisions, as follows: Cyanophyta (39); Chlorophyta/Chlorophyceae (36); Bacillariophyta/Bacillariophyceae (10); Zignemaphyta/Zygnemaphyceae (08); Euglenophyta/Euglenophyceae (04); Chrysophyta/Chrysophyceae (03); Dinophyta/Dinophyceae (02); Xanthophyta/Xanthophyceae (01). In the distribution of the taxonomic classes, the class Cyanophyceae (38\%) and Chlorophyceae (35\%) were the ones that contributed the most to the richness of taxa in the phytoplankton community (Fig. 5).

After separation of the samples collected at the RT-E2 and RT-E4 stations, where the Chlorophyll ' $a$ ' analysis were performed, each sample was checked until a counting efficiency of more than $80 \%$ was reached 
(PAPPAS et al., 1996), comprising a total of 3,910 individuals from which 2,855 belong to the Cyanophyta division. Fig. 6 shows the distribution of population density by percentage in both sampling stations.

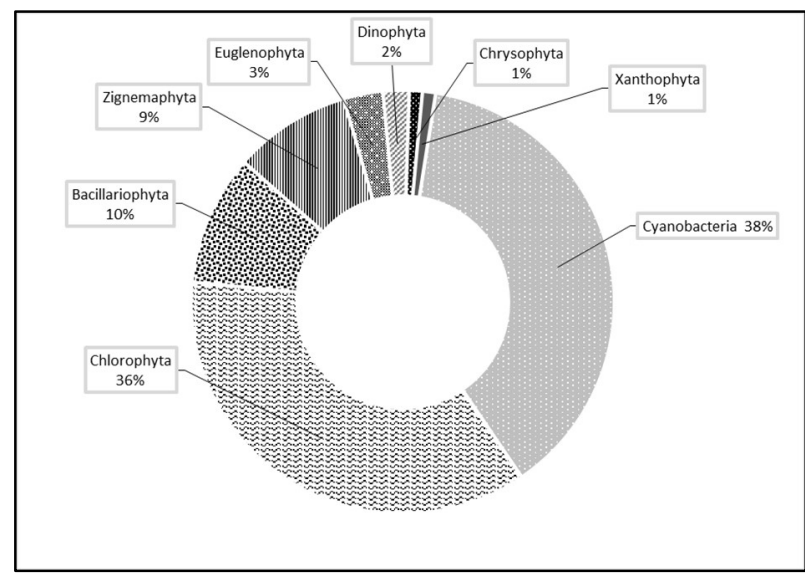

Fig. 5: Relative contribution of phytoplankton taxonomic classes.

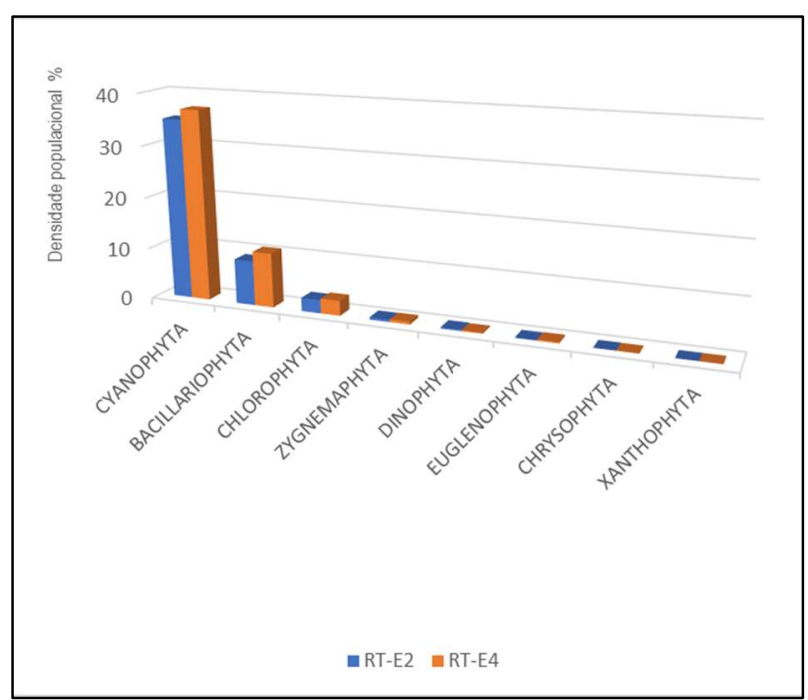

Fig. 6: Percentage contribution of the phytoplankton population density in the stations RT-E2 and RT-E4.

Because they are extremely adaptable and intelligent, cyanobacteria use mechanisms that allow them to have dominance over the other taxonomic classes, in a system that more closely resembles cooperation with a percentage of advantage, than to competition over the other taxonomic classes. As for the presence of cyanobacteria in the blooms occurring in the study area, the following species were dominant: Synechocystis aquatilis (\%), Microcystis aeruginosa (\%), Dolichospermum spiroides (\%) e Nostoc sp. (\%).

\section{Toxins}

Except for S. aquatilis, which was abundantly found, all other dominant cyanobacteria species in the analysed samples are potentially producers of cyanotoxin, which can indeed be released into the water after cell disruption.

There is also the bloom that form in the channel of the river and spread and cause the accumulation of the scum in the margins. Over two or three days, fragments of a the bloom can descend toward the mouth and enter the spaces between the riverboats in the port area, and accumulate on the banks in front of the edge of Santarém. Fragments of senescence the blooms present the greatest potential for cyanobacterial cell disruption with release of toxic substances in the water, especially when they get in friction with boats entering and exiting the ports. However, the toxicity of cyanobacteria varies from species to species, and within the same genus there may be producing and non-toxin producing strains, also called cyanotoxins. Cyanotoxins are classified according to the pharmacological action, such as hepatotoxins, neurotoxins and dermatotoxins, and human exposure may occur through dermal contact, by inhalation, or by oral ingestion (e.g., water supply or accidentally in recreational activities), via intravenous (in the case of haemodialysis), and by bioaccumulation in the food chain (ALVES, 2006), Table 4. 
Table 4: Toxic groups cyanobacteria present in the lower Tapajós River Basin considering class, mechanism of action, tolerable daily intake, lethal dose (rats), primary target (affected organs) and effects on human health.

\begin{tabular}{|c|c|c|c|c|c|c|c|c|}
\hline Toxin Group & Class & $\begin{array}{l}\text { Action } \\
\text { mechanisms }\end{array}$ & $\begin{array}{l}\text { Tolerab } \\
\text { le daily } \\
\text { intake } \\
\text { (TDI) }\end{array}$ & $\begin{array}{l}\text { Letha } \\
\text { I dose } \\
\text { ( } \mu \mathrm{g} / \mathrm{k} \\
\mathrm{g} \text { ) }\end{array}$ & $\begin{array}{l}\text { Primary } \\
\text { target }\end{array}$ & $\begin{array}{l}\text { Effects } \\
\text { human health }\end{array}$ & $\begin{array}{l}\text { Cyanobacterial } \\
\text { species }\end{array}$ & $\begin{array}{l}\text { Drinki } \\
\text { ng } \\
\text { water } \\
\text { quality }\end{array}$ \\
\hline \multicolumn{9}{|l|}{ Ciclic peptide } \\
\hline Microcystine & $\begin{array}{l}\text { Cyanoto } \\
\text { xin }\end{array}$ & $\begin{array}{l}\text { Protein } \\
\text { phosphatase } \\
\text { blockers }\end{array}$ & $\begin{array}{l}0,4 \\
\mu \mathrm{g} / \mathrm{kg}\end{array}$ & $\begin{array}{l}45- \\
1000\end{array}$ & Liver & $\begin{array}{l}\text { Abdominal } \\
\text { pain } \\
\text { Vomiting } \\
\text { and } \\
\text { diarrhea } \\
\text { Liver } \\
\text { inflammati } \\
\text { on and } \\
\text { hemorrha } \\
\text { ge } \\
\text { Acute } \\
\text { pneumoni } \\
\text { a } \\
\text { Acute } \\
\text { dermatitis } \\
\text { Kidney } \\
\text { damage } \\
\text { Potential } \\
\text { tumor } \\
\text { growth } \\
\text { promotion }\end{array}$ & $\begin{array}{l}\text { Mirocystis, } \\
\text { Mictcrocystis } \\
\text { aeruginosa; } \\
\text { Microsystis } \\
\text { botrys; } \\
\text { Microsystis } \\
\text { panniformis; } \\
\text { Microsystis } \\
\text { protocystis; } \\
\text { Microcystis } \\
\text { wasenbergii } \\
\text { Nostoc }\end{array}$ & $\begin{array}{l}0,3^{5}- \\
1,0^{6} \\
\mu g / k g \\
\text { (WHO, } \\
1998)\end{array}$ \\
\hline
\end{tabular}

\begin{tabular}{|c|c|c|c|c|c|c|c|c|}
\hline \multirow{2}{*}{\multicolumn{9}{|c|}{ Alkaloids }} \\
\hline & & & & & & & & \\
\hline $\begin{array}{l}\text { Cylindropermo } \\
\text { psin }\end{array}$ & $\begin{array}{l}\text { Cytotoxi } \\
n\end{array}$ & $\begin{array}{l}\text { Block protein } \\
\text { synthesis; } \\
\text { substancial } \\
\text { cumulative } \\
\text { toxicity }\end{array}$ & -2 & $\begin{array}{l}200- \\
2.100\end{array}$ & $\begin{array}{l}\text { multiple } \\
\text { organs (liver, } \\
\text { kidney, } \\
\text { spleen, } \\
\text { gastrointesti } \\
\text { nal tract, } \\
\text { heart, } \\
\text { thymus and } \\
\text { skin) }\end{array}$ & $\begin{array}{l}\text { Abdominal } \\
\text { pain } \\
\text { Vomiting and } \\
\text { diarrhea } \\
\text { Liver } \\
\text { inflammation } \\
\text { and } \\
\text { hemorrhage } \\
\text { Acute } \\
\text { pneumonia } \\
\text { Acute } \\
\text { dermatitis } \\
\text { Kidney } \\
\text { damage } \\
\text { Potential } \\
\text { tumor growth } \\
\text { promotion }\end{array}$ & $\begin{array}{l}\text { Cylindropermo } \\
\text { psis sp. }\end{array}$ & $0,7^{5}$ \\
\hline Saxitoxin & $\begin{array}{l}\text { Neuroto } \\
\text { xin }\end{array}$ & $\begin{array}{l}\text { Block } \\
\text { acetylcholinester } \\
\text { ase; block } \\
\text { sodium channels }\end{array}$ & -2 & $10-30$ & Axon nerve & $\begin{array}{l}\text { eye irritation, } \\
\text { abdominal; } \\
\text { pain }^{3-;} \\
\text { paralysis, } \\
\text { death }^{4}\end{array}$ & $\begin{array}{l}\text { Dolichospermu } \\
\text { m sp.; } \\
\text { Dolichospermu } \\
m \text { spiroides; } \\
\text { Aphanizomeno } \\
n \quad \text { sp.; } \\
\text { Cylidropermop } \\
\text { sis sp. }\end{array}$ & - \\
\hline Anatoxin-a & $\begin{array}{l}\text { Neuroto } \\
\text { xin }\end{array}$ & $\begin{array}{l}\text { Block post- } \\
\text { synaptic } \\
\text { depolarization }\end{array}$ & -2 & 250 & $\begin{array}{l}\text { sympathetic } \\
\text { nerve }\end{array}$ & $\begin{array}{l}\text { Tingling, } \\
\text { burning, } \\
\text { numbness, } \\
\text { drowsiness, } \\
\text { incoherent }\end{array}$ & $\begin{array}{l}\text { Dolichospermu } \\
m \text { sp. } \\
\text { Dolichospermu } \\
m \text { spiroides; } \\
\text { Aphanizomeno }\end{array}$ & - \\
\hline
\end{tabular}




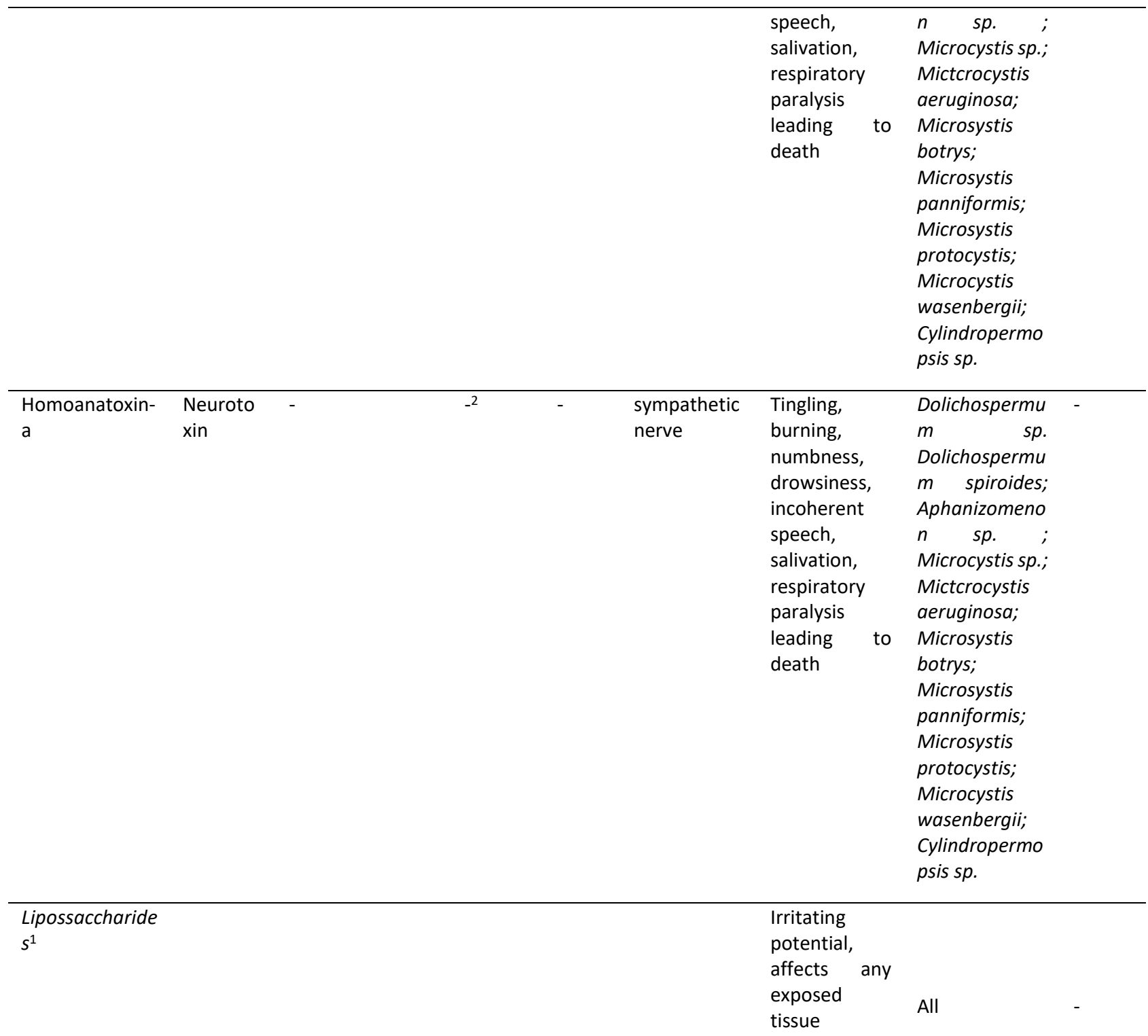

\footnotetext{
${ }^{1}$ Liposaccharides (LPS) are components of the cell membrane of cyanobacteria, and are pyrogenic endotoxins, capable of producing skin irritations and allergies. These compounds are especially important in places at risk of exposure to cyanobacterial cells, such as those intended for bathing (CETESB, 2013).

${ }^{2}$ According Toxic Cyanobacteria in Water: A guide to their public health consequences, monitoring and management (1999), the database is insufficient for the derivation of the TDI.

${ }^{3}$ (RAPALA et al., 2005)

${ }^{4}$ (TESTAl et al., 2016)

${ }^{5}$ EPA (Cyanobacteria and Cyanotoxins: Information for Drinking Water Systems. 2019)

${ }^{6}$ World Health Organization (1998)
}

The dominant genus mentioned in this work (Microcystis, Dolichospermum and Nostoc), belong to the main cyanobacterial genera of toxins, of the hepatotoxins group, which comprises the nodularin, the cylindrospermopsin and the microcystin, that affect human liver cells and can generate persistent inflammatory processes. These species are more frequent and therefore pose a greater risk to health, since hepatotoxins have a bio-accumulative action and may at the molecular level act as an inhibitor of the proteins phosphatase 1 (PP1) and 2A (PP2A), and in the long term contribute to the development of hepatic cancerous tumours. 


\section{Occurrence and Identification}

In this study, the identification of cyanobacteria was made by observing the morphological and morphometric characteristics of the organisms, based on specific literature (BICUDO et al., 2006; ALVES, 2006; LAMPARELLI et al., 2014; SANT'ANNA, 2006), Table 5. The frequency of occurrence of each genus and/or species follows the classification described in the study entitled Potential of Cyanobacteria The bloom in a Domestic Supply Reservoir in the State of Espírito Santo: Duas Bocas Reservoir - Cariacica - ES, where the genera and species found are listed in their respective taxonomic divisions, followed by the letter (s) of occurrence frequency, as for example: Dolichospermum spiroides (Klebahn) Walcklin, Hoffmanng \& Komárek $=\mathrm{D} / \mathrm{CT}$ (dominant species in numbers and constant in most fields counted per sample), Table 5.

Table 5: Distribuition of frequency of algae in this study. $\mathbf{D}=$ dominant; $\mathbf{A}=$ abundant; $\mathbf{C T}=$ constant; $\mathbf{C M}=$ common; $\mathbf{R}$ $=$ rare.

\begin{tabular}{|c|c|c|}
\hline Divisão & Species & Frequency \\
\hline 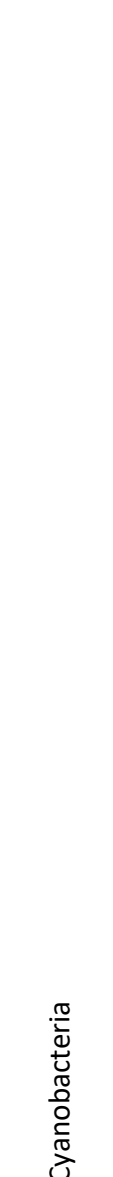 & $\begin{array}{l}\text { Aphanizomenon sp. A.Morren ex É.Bornet \& C.Flahault } \\
\text { Anathece sp. (Komárek \& Anagnostidis) Komárek, Kastovsky \& Jezberová } \\
\text { Aphanocapsa elachista West \& G.S.West } \\
\text { Aphanocapsa sp. C.Nägeli } \\
\text { Chroococcus sp. Nägeli } \\
\text { Chroococcus dispersus (Keissler) Lemmermann } \\
\text { Cylindrospermopsis sp. G.Seenayya \& N.Subba Raju } \\
\text { Coelomoron tropicale P.A.C.Senna, A.C.Peres \& Komárek } \\
\text { Coelosphaerium sp. Nägeli } \\
\text { Cuspidothrix sp. P.Rajaniemi, J.Komárek, R.Willame, P.Hrouzek, K.Kastovská, L.Hoffmann \& K.Sivonen } \\
\text { Dolichospermum planctonicum (Brunnthaler) Wacklin, L.Hoffmann \& Komárek } \\
\text { Dolichospermum sp. (Ralfs ex Bornet \& Flahault) P.Wacklin, L.Hoffmann \& J.Komárek } \\
\text { Dolichospermum spiroides (Klebahn) Walcklin, Hoffmanng \& Komárek } \\
\text { Geitlerinema sp. (Anagnostidis \& Komárek) Anagnostidis } \\
\text { Merismopedia sp. Meyen } \\
\text { Merismopedia tenuissima Lemmermann } \\
\text { Merismopedia trolleri Bachmann } \\
\text { Microcystis aeruginosa (Kützing) Kützing } \\
\text { Microcystis botrys Teiling } \\
\text { Microcystis panniformis Komárek, Komárková-Legnerová, Sant'Anna, M.T.P. Azevedo, \& P.A.C. Senna } \\
\text { Microcystis protocystis Crow } \\
\text { Microcystis wesenbergii (Komárek) Komárek ex Komárek } \\
\text { Microcystis sp. Lemmermann } \\
\text { Nostoc sp. Vaucher ex Bornet \& Flahault } \\
\text { Pseudanabaena galeata Böcher } \\
\text { Pseudanabaena sp. Lauterborn } \\
\text { Rhabdoderma lineare Schmidle \& Lauterborn } \\
\text { Sphaerocavum sp. M.T. de P.Azevedo \& C.L.Sant'Anna } \\
\text { Synechocystis aquatilis Sauvageau } \\
\text { Woronichinia sp. A.A.Elenkin } \\
\text { Woronichinia naegeliana (Unger) Elenkin }\end{array}$ & \begin{tabular}{|l}
$\mathrm{R}$ \\
$\mathrm{CM}$ \\
$\mathrm{CT}$ \\
$\mathrm{R}$ \\
$\mathrm{CM}$ \\
$\mathrm{CM} / \mathrm{CT}$ \\
$\mathrm{R}$ \\
$\mathrm{R}$ \\
$\mathrm{R}$ \\
$\mathrm{R}$ \\
$\mathrm{CM}$ \\
$\mathrm{CM}$ \\
$\mathrm{D} / \mathrm{CT}$ \\
$\mathrm{CM}$ \\
$\mathrm{CT}$ \\
$\mathrm{R}$ \\
$R$ \\
$\mathrm{CM} / \mathrm{D}$ \\
$\mathrm{R}$ \\
$\mathrm{R}$ \\
$\mathrm{R}$ \\
$\mathrm{R}$ \\
$\mathrm{CT}$ \\
$\mathrm{CM} / \mathrm{D}$ \\
$\mathrm{A} / \mathrm{CM}$ \\
$\mathrm{A} / \mathrm{CT}$ \\
$\mathrm{A} / \mathrm{CT}$ \\
$\mathrm{CM}$ \\
$\mathrm{A} / \mathrm{D}$ \\
$\mathrm{CM}$ \\
$\mathrm{R}$ \\
\end{tabular} \\
\hline $\begin{array}{l}\frac{\pi}{2} \\
\frac{\mathbb{C}}{0} \\
\frac{0}{0} \\
\frac{0}{\mathrm{C}}\end{array}$ & $\begin{array}{l}\text { Ankistrodesmus sp. Corda } \\
\text { Asterocapsa sp. H.-J.Chu } \\
\text { Botryococcus sp. Kützing } \\
\text { Chlorococcum sp. Meneghini } \\
\text { Chlorotetraedron incus (Teiling) Komárek \& Kovácik) } \\
\text { Chodatellopsis elliptica Korshikov } \\
\text { Closterium sp. Nitzsch ex Ralfs } \\
\text { Cosmarium sp. Corda ex Ralfs } \\
\text { Crucigenia sp. Morren } \\
\text { Desmodesmus armatus (Chodat) E.H.Hegewald } \\
\text { Desmodesmus intermedius (Chodat) E. Hegewald } \\
\text { Desmodesmus sp. (Chodat) S.S.An, T.Friedl \& E.Hegewald } \\
\text { Desmodesmus spinosus (Chodat) E. Hegewald } \\
\text { Didymocystis sp. Korshikov }\end{array}$ & $\begin{array}{l}R \\
R \\
R / R \\
C M \\
R \\
R \\
R \\
C M \\
A / R \\
C T \\
A / C M \\
C T \\
C M \\
R\end{array}$ \\
\hline
\end{tabular}




\begin{tabular}{|c|c|c|}
\hline & $\begin{array}{l}\text { Dimorphococcus sp. Braun } \\
\text { Elakatotrix gelatinosa Wille } \\
\text { Eutetranorus sp. Walton } \\
\text { Geminela sp. Turpin } \\
\text { Glaucocystis nostochinearum Itzigsohn } \\
\text { Glaucocystis sp. Itzigsohn } \\
\text { Keratococcus bicaudatus (A. Braren) J. B. Petersen } \\
\text { Koliella sp. Hindák } \\
\text { Microspora sp. Thuret } \\
\text { Micrasterias sp. C.Agardh ex Ralfs } \\
\text { Monoraphidium contortum (Thuret) Komárkova - Legnerová } \\
\text { Nephrocytium sp. Nägeli } \\
\text { Onychonema sp. Wallich } \\
\text { Pectodictyon sp. Taft } \\
\text { Pediastrum duplex Meyen } \\
\text { Pediastrum simplex Meyen } \\
\text { Phytelios viridis Frenzel } \\
\text { Rhizoclonium sp. Kützing } \\
\text { Scenedesmus acuminatus (Lagerheim) Chodat } \\
\text { Scenedesmus linearis Komárek } \\
\text { Schroederia sp. Lemmermann } \\
\text { Staurastrum sp. Meyen ex Ralfs } \\
\text { Treubaria sp. C. Bernard } \\
\text { Zinemaphyceae sp.1 } \\
\text { Zignemaphyceae sp.2 }\end{array}$ & $\begin{array}{l}\text { CM } \\
R \\
R \\
R \\
R \\
R \\
C T \\
R \\
C M \\
R \\
C T / C M \\
C M \\
R \\
R \\
C T / C M \\
A / D \\
C M \\
R \\
C M / C T \\
C M / C T \\
C M \\
A / C T \\
R \\
C T / C M \\
A / C M\end{array}$ \\
\hline 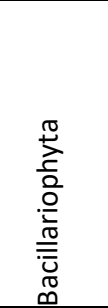 & $\begin{array}{l}\text { Aulacoseira granulata (Ehrenberg) Simonsen } \\
\text { Aulacoseira sp. Thwaites } \\
\text { Diploneis sp. Ehrenberg ex Cleve } \\
\text { Navicula sp. Bory } \\
\text { Urosolenia sp. Round \& Crawford } \\
\text { Bacillariophyceae sp. } 1 \\
\text { Bacillariophyceae sp. } 2 \\
\text { Coscinodiscophyceae }\end{array}$ & $\begin{array}{l}\mathrm{A} / \mathrm{CM} \\
\mathrm{A} / \mathrm{CT} \\
\mathrm{R} \\
\mathrm{CT} / \mathrm{A} \\
\mathrm{CM} \\
\mathrm{A} / \mathrm{CM} \\
\mathrm{CT} / \mathrm{A} \\
\mathrm{R}\end{array}$ \\
\hline 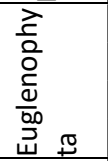 & $\begin{array}{l}\text { Euglena sp. Ehrenberg } \\
\text { Heteronema sp. Dujardin } \\
\text { Euglenophyceae sp.1 } \\
\text { Euglenophyceae sp. } 2\end{array}$ & \begin{tabular}{|l|}
$\mathrm{A} / \mathrm{CT}$ \\
$\mathrm{R}$ \\
$\mathrm{A} / \mathrm{CT}$ \\
$\mathrm{CM}$ \\
\end{tabular} \\
\hline 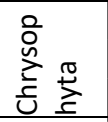 & $\begin{array}{l}\text { Chrysococcus ellipsoideus Ettlo } \\
\text { Dinobryon sp. Ehrenberg } \\
\text { Chlamydomonas sp. Ehrenberg }\end{array}$ & $\begin{array}{l}\mathrm{R} \\
\mathrm{R} \\
\mathrm{R} \\
\end{array}$ \\
\hline 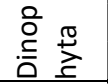 & $\begin{array}{l}\text { Peridiniopsis sp. Lemmermann } \\
\text { Dinophyceae sp. } 1\end{array}$ & \begin{tabular}{|l|}
$\mathrm{CT} / \mathrm{A}$ \\
$\mathrm{CM}$ \\
\end{tabular} \\
\hline$\ddot{x} \pm$ & Raphidiella fascicularis Pascher & $\mathrm{R}$ \\
\hline
\end{tabular}

As seen above, among the five-dominant species found in this study, four of them are potentially producing cyanotoxins, namely: Microcystis aeruginosa, Dolichospermum spiroides and Nostoc. They are species belonging to the main genera of toxin-producing cyanobacteria that may affect human liver cells and can generate persistent inflammatory processes, which in turn can sometimes confuse the diagnosis of diseases, as being derived from viral pathogenesis.

\section{CONCLUSIONS}

The studied transect of the Tapajós river, in front of the border of Santarém, presented most of the physicochemical parameters within the allowed standard for the rivers classified as Class 2, according to CONAMA Resolution \# 357/2005 (MMA, 2005). However, dissolved oxygen has been shown to be below the permitted standard, indicating water pollution in the margins up to the depth studied, i.e., the average of 2.3 meters of depth, depending on the access site and the sampling station. 
The presence of cyanobacteria potentially producing cyanotoxins is of concern and may play a relevant role if considered while diagnosing local diseases, such as sudden outbreaks of hepatic infections observed in riverine communities in the region. However, there is a need for more in-depth studies on the toxicity potential to the human population and other aquatic organisms living in the Tapajós River, which in turn might be used to guide the population through public health and environmental education programs.

AKNOWLEDGMENTS: The authors express their gratitude to the professors, technicians and other collaborators who directly or indirectly contributed to the success of this study. Sincere thanks to Professor Oscar Vega of the Centre for Environment Chemistry of the University of São Paulo as well as professors Célia Sant'Anna and Luciana Retz of the Institute of Botany of São Paulo for the kindness in the sharing of knowledge. Our thanks to UFOPA through the Laboratories of Applied Chemistry, Biology, and Microscopy as well as other physical and organizational structures that allowed the conduction of this research and gave opportunity for improvement in partner institutions. We are also grateful for the attention and support of the management sectors of Beira-Rio Glacier, Santarém City Hall and Port Control Company of the State of Pará, which allowed access to the sampling sites.

\section{REFERENCES}

ABDO, J. M. M.; BENEVIDES, V. F. S.; COIMBRA, R. M.; LOURD, M.; FRITSCH, J. M.. HIBAM: Hidrologia da Bacia Amazônica: décima campanha de amostragem de água e sedimentos nas bacias dos rios Tocantins, Xingu e Tapajós, Brasília, Marabá, Altamira, Itaituba. ANA, 1997.

ANA. Agência Nacional de Águas. Panorama da qualidade das águas superficiais do Brasil. ANA, 2012.

ALVES, M. S. A.. Cianobactérias e cianotoxinas em águas continentais. Tese (Doutorado) - Universidade de São Paulo, São Paulo, 2006

APHA. American Public Health Association. Standard methods for the examination of water and wastewater. APHA, 1915.

AZEVEDO, S. M. F. O.; BRANDÃO, C. C. S.. Cianobactérias tóxicas na água para consumo humano na saúde pública e processos de remoção em água para consumo humano. Brasília: Ministério da Saúde, 2003.

BICUDO, C. E. M.; MENEZES, M.. Gêneros de algas de águas continentais do Brasil. São Carlos, Rima, 2006.

BRASIL. Ministério da Saúde. PORTARIA N. 2.914,12 de dezembro de 2011. Brasília: MS, 2001.

CARVALHO, M. C.; AGUJARO, L. F.; PIRES, D. A.; PICOLI, C.. Manual de cianobactérias planctônicas: legislação, orientações para o monitoramento e aspectos ambientais. Sao Paulo: Secretaria do Meio Ambiente, 2013.

CETESB. Companhia Ambiental do Estado de São Paulo. Manual de cianobactérias planctônicas: legislação, orientações para o monitoramento e aspectos ambientais. São Paulo: CETESB, 2013.

ESTEVES, F. A.. Fundamentos de limnologia. 2011.

GENTIL, R. C.; TUCCI, A.; SANT'ANNA, C. L.. Dinâmica da comunidade fitoplanctônica e aspectos sanitários de um lago urbano eutrófico em São Paulo, SP. Hoehnea, v.35, n.2, p.265-280, 2008 .

HUSZAR, V. L. M.; SILVA, L. H. S.; MARINHO, M.; DOMINGOS, P.; SANT'ANNA, C. L.. Cyanoprokaryote assemblages in eight productive tropical Brazilian waters. In: REYNOLDS, C. S.; DOKULIL, M.; PADISÁK, J.. The Trophic Spectrum Revisited. Developments in Hydrobiology, Springer, v.150. 2000. p.6777. DOI: https://doi.org/10.1007/978-94-017-3488-2 6

IBGE. Instituto Brasileiro de geografia e Estatística. Censo demográfico. IBGE, 2010

LAMPARELLI, M. C.; TUCCI, A.; SANT'ANNA, C. L.; PIRES, D. A.; LERCHE, L. H. M.; CARVALHO, M. C.; ROSAL, C.. Atlas de cianobactérias da bacia do Alto Tietê. Sao Paulo: CETESB, 2014.

MATTHIENSEN, A.; YUNES, J. S.; CODD, G. A.. Ocorrência, distribuição e toxicidade de cianobactérias no estuário da Lagoa dos Patos, RS. Revista Brasileira de Biologia, v.59, n.3, p.361-376, 1999. DOI: https://doi.org/10.1590/S003471081999000300002

MIRANDA, R. G.; PEREIRA, S.; ALVES, D.; OLIVEIRA, G.. Qualidade dos recursos hídricos da Amazônia-Rio Tapajós: avaliação de caso em relação aos elementos químicos e parâmetros físico-químicos. Ambiente \& Água-An 
Interdisciplinary Journal of Applied Science, v.4, n.2, p.7592, 2009.

MMA. Ministério do Meio Ambiente. Resolução CONAMA n. 357, de 17 de março de 2005. Diário Oficial da República Federativa do Brasil, Poder Executivo, Brasília-Distrito Federal, n. 53, Seção 1, p. 58-63. Alterada pelas Resoluções no 370, de 2006, no 397, de 2008, no 410, de 2009, e no 430, de 2011. Complementada pela Resolução no 393, de 2009. Brasília: MMA, 2005

PAPPAS, J. L.; STOERMER, E. F.. Quantitative method for determining a representative algal sample count 1 . Journal of Phycology, v.32, n.4, p.693-696, 1996.

RAPALA, J.; ROBERTSON, A.; NEGRI, A. P.; BERG, K.; TUOMI, P.; LYRA, C.; ERKOMAA, K.; LAHTI, K.; HOPPU, K.; LEPISTÖ, L.. First report of saxitoxin in Finnish lakes and possible associated effects on human health. Environmental Toxicology: An International Journal, v.20, n.3, p.331-340, 2005.

REBOUÇAS, A. C.; BRAGA, B.; TUNDISI, J. G.. Águas doces do Brasil: Capital ecológico, uso e conservação. 3 ed. 2006.

SÁ, L. L. C.; VIEIRA, J. M. S.; MENDES, R. A.; PINHEIRO, S. C. C.; VALE, E. R.; ALVES, F. A. S.; JESUS, I. M.; SANTOS, E. C. O.; COSTA, V. B.. Ocorrência de uma floração de cianobactérias tóxicas na margem direita do Rio Tapajós, no Município de Santarém (Pará, Brasil). Rev. Pan-Amaz. Saúde, v.1, n.1, 2010. DOI: http://dx.doi.org/10.5123/S2176$\underline{62232010000100022}$
SANT'ANNA, C. L.. Manual ilustrado para identificação e contagem de cianobactérias planctônicas de águas continentais brasileiras. Rio de Janeiro : Interciência; São Paulo: Sociedade Brasileira de Ficologia, 2006.

SANTOS, C. A.; SERRÃO, E. A. O.; GONÇALVES, L. J. M.; WANZELER, R. T. S.; LIMA, A. M. M.. Zoneamento da distribuição da precipitação pluviométrica na bacia hidrográfica do rio tapajós. Enciclopédia Biosfera, Goiânia, v.10, n.18, p.3092-3106, 2014.

SIOLI, H.. Amazônia: fundamentos da ecologia da maior região de florestas tropicais. Petrópolis: Vozes, 1991.

STRICKLAND, J. D. H.; PARSONS, T. R.. A manual of sea water analysis (Bulletin 125). 2 ed. Fisheries Research Board of Canada, 1965.

TEIXEIRA, C.. Introdução aos métodos para medir a produção primária do fitoplâncton marinho. Boletim do Instituto Oceanográfico, v.22, p.59-92, 1973.

TESTAI, E.; BURATTI, F. M.; FUNARI, E.; MANGANELLI, M.; VICHI, S.; ARNICH, N.; BIRÉ, R.; FESSARD, V.; SIALEHAAMOA, A.. Review and analysis of occurrence, exposure and toxicity of cyanobacteria toxins in food. EFSA Supporting Publications, v.13, n.2, p.998E, 2016.

UTERMÖHL, H.. Zur vervollkommnung der quantitativen phytoplankton-methodik: Mit 1 Tabelle und 15 abbildungen im Text und auf 1 Tafel. Internationale Vereinigung für theoretische und angewandte Limnologie: Mitteilungen, v.9, n.1, p.1-38, 1958.

A CBPC - Companhia Brasileira de Produção Científica (CNPJ: 11.221.422/0001-03) detém os direitos materiais desta publicação. Os direitos referem-se à publicação do trabalho em qualquer parte do mundo, incluindo os direitos às renovações, expansões e disseminações da contribuição, bem como outros direitos subsidiários. Todos os trabalhos publicados eletronicamente poderão posteriormente ser publicados em coletâneas impressas sob coordenação da Sustenere Publishing, da Companhia Brasileira de Produção Científica e seus parceiros autorizados. Os (as) autores (as) preservam os direitos autorais, mas não têm permissão para a publicação da contribuição em outro meio, impresso ou digital, em português ou em tradução. 